\title{
Teacher Role Breadth and its Relationship to Student-Reported Teacher Support
}

Kate L. Phillippo

Loyola University Chicago, kphillippo@luc.edu

Susan Stone

University of California, Berkeley

Follow this and additional works at: https://ecommons.luc.edu/education_facpubs

Part of the Education Commons

\section{Recommended Citation}

Phillippo, K and S Stone. "Teacher Role Breadth and its Relationship to Student-Reported Teacher Support." The High School Journal 96(4), 2013.

This Article is brought to you for free and open access by the Faculty Publications and Other Works by Department at Loyola eCommons. It has been accepted for inclusion in Education: School of Education Faculty Publications and Other Works by an authorized administrator of Loyola eCommons. For more information, please contact ecommons@luc.edu. (c) (i) (9)

This work is licensed under a Creative Commons Attribution-Noncommercial-No Derivative Works 3.0 License. From High School Journal, Vol. 96(4), 358-379 . Copyright @ 2013 by the University of North Carolina Press. Used by permission of the publisher. www.uncpress.unc.edu 


\title{
Teacher Role Breadth and its Relationship to Student-Reported Teacher Support
}

\author{
Kate L. Phillippo \\ Loyola University Chicago \\ kphillippo@luc.edu \\ Susan Stone \\ University of California, Berkeley \\ sistone@berkeley.edu
}

\begin{abstract}
This study capitalizes on a unique, nested data set comprised of students ( $\mathrm{n}=531$ ) and teachers $(\mathrm{n}=45)$ in three high schools that explicitly incorporated student support roles into teachers' job descriptions. Drawing from research on student-teacher relationships, teacher effects on student outcomes, and role theory, this study explored correlates of teachers' role definition. In particular, it considered role breadth, or the degree to which teachers defined their roles to include the provision of various forms of social and emotional support to students. We hypothesized that teachers' role breadth would relate to student perceptions of teacher support and high academic expectations (also known as academic press). Multi-level modeling of the relationship between teacher role breadth and student outcomes accounted for the data's nested quality and showed a positive relationship between teachers' sense of efficacy about providing student support and their reported role breadth. In addition, teacher role breadth was positively related to student perceptions of teacher support and academic press, controlling for student-reported background and school performance characteristics. Implications for student-teacher relationships, teacher education, and teacher roles are discussed.
\end{abstract}

Keywords: student-teacher relationships, role theory, teacher roles, teacher support, academic press, teacher personalism, teacher caring, teacher effects, advisory programs

\section{Introduction}

In recent years, academic, policy and popular discussions about education have increasingly emphasized teachers' central role in promoting student academic growth (Cuban, 2010; Hanushek, 2011; Kumashiro, 2012). This emphasis on teachers challenges those concerned with education to consider how teachers' practice directly influences what and how students learn, and what can be done to support teachers' essential contributions. This focus tends to zero in on teachers' impact upon students' measured academic performance, as is demonstrated in recent debates about the use of student performance data to gauge a teacher's effectiveness (Darling-Hammond, Haertel, Amrein-Beardsley, \& Rothstein, 2012; Garland, 2012; Rothstein, 2012). Recent events—such as the controversial publication of New York City and Los Angeles schoolteachers' individual effectiveness ratings and the dispute during the 2012 Chicago Teachers Union's strike about the amount of emphasis that 
teacher evaluation processes would place on their students' test scores-highlight the attention given to individual teachers' contributions to student growth. A view of teachers' impact on student outcomes as strictly or simply academic in nature, however, misses the opportunity to understand different, and sometimes indirect, routes of influence that teachers have on student learning and development.

This article expands the body of literature on how teachers can contribute to student outcomes associated with academic achievement. It considers the relationship between teachers' role breadth-which we define as the extent to which teachers include the social and emotional support of students in their definition of their professional responsibilities ${ }^{1}$ —and students' perceptions of teacher support. Recent scholarship highlights how student social-emotional concerns like peer harassment (Hill \& Kearl, 2011; Martin-Storey \& Crosnoe, 2012; Robinson \& Espelage, 2011 \& 2012) and homelessness (Hallett, 2011; Miller, 2011) can impinge on students' school attendance, engagement, and performance. Meanwhile, an emerging body of literature suggests that teachers may play important roles, particularly in terms of their relationships with students, in addressing student social-emotional functioning (Johnson, Eva, Johnson \& Walker, 2011; Mihalas, Morse, Allsopp, \& McHatton, 2009).

The work of building relationships specifically oriented towards students' socialemotional wellness, however, stretches beyond conventional parameters of teacher roles, which tend to focus on curriculum and instruction (Lortie, 2002). Teachers who serve as student advisors-providing academic and social-emotional support to students in a formally assigned mentoring relationship that often spans multiple school years-stand as a notable exception to this tendency (Burns, Jenkins \& Kane, 2011; Lieber \& Poliner, 2004). Though limited, research on advisory programs (Anfara, 2006; Galassi, Gulledge \& Cox, 1997; Shulkind \& Foote, 2009) suggests that secondary school students do benefit from regular personal contact with an assigned advisor, where the advisor tends to develop an extended relationship with student advisees, oversees students' academic progress, and intervenes when problems arise. Still, even within the context of formal advisory programs, teachers enact the advisor role in different ways, with foci as diverse as college readiness, team building, and individual mentoring (Phillippo, 2010). Such findings suggest important variation across teachers in terms of whether and how they provide support to students, as well as variation in the benefits of this support. McClure, Yonezawa, and Jones (2010) found a positive association between students' perceptions of teacher support and their academic performance but a negative relationship between students' perceptions of advisor support and academic performance. Thus, not enough is known about how teacher support, particularly formalized teacher support as required by the advisor role, benefits students.

These combined findings suggest a need for deeper inquiry about the extent to which teachers' inclusion of student support among their responsibilities relates to academically salient student outcomes. For this reason, we explored whether teachers' role breadth (related to providing social and emotional support to students) would relate to variation in student reported teacher support and academic press (high expectations for student performance), two well-established indicators of effective student-teacher relationships (Bryk, Sebring, Allensworth, Luppescu, \& Easton, 2010).

1 We adopt the term "role breadth" from Somech and Oplatka (2009), who used it to describe the degree to which teachers included in their role the responsibility to address violence in school and in the classroom. 
Given the emerging nature of this area of inquiry, we grounded our study in three bodies of literature-research on student-teacher relationships, teacher effects on student outcomes, and role theory-in order to connect teachers' role definition and students' perceptions of their relationships with their teachers. Our findings suggest that teachers' inclusion of student support in their role definition contributes to students' experiences of support and academic press. We conclude this article by discussing implications for how teachers' work is organized and supported, in the name of promoting optimal student outcomes.

\section{Background}

\section{Student-Teacher Relationships: Research and Related Policy}

The quality of relationships between students and teachers has garnered substantial attention in recent decades as a catalyst for promoting student achievement and well-being. Because researchers have consistently found positive association between strong student-teacher relationships and students' academic engagement (Brewster \& Bowen, 2004; Hughes \& Kwok, 2007; Hughes, Luo, Kwok \& Loyd, 2008; Klem \& Connell, 2004; Rosenfeld, Richman, Bowen, \& Wynns, 2006) and academic achievement (Roorda, Koomen, Spilt, \& Oort, 2011), these relationships are often understood as a powerful form of social capital. Among various interpretations of social capital (e.g., Coleman, 1988; Lin, 2001), Bourdieu's (1986) definition of social capital-social relationships that can convert into economic and other tangible benefits-particularly highlights how student-teacher relationships can confer a range of advantages and assets upon students. These relationships have been found to promote students' sense of academic efficacy (Lewis et al., 2012), boost struggling students' academic performance (Crosnoe et al., 2010; Hamre \& Pianta, 2005; Muller, 2001), and increase students' likelihood of transitioning successfully into high school (Langenkamp, 2010), graduating on time (Croninger \& Lee, 2001), and attending college (Erickson, MacDonald \& Elder, 2009). Strong student-teacher relationships can benefit students via institutional support (Stanton-Salazar, 2010), in which teachers and the social networks they can access help students navigate bureaucratic systems, decode and engage in unfamiliar cultural practices, connect to subsequent learning and work opportunities, and acquire social and academic guidance (Stanton-Salazar, 1997, 2010).

Student-teacher relationships also promote student resiliency. Longitudinal studies (Hetherington \& Kelly, 2002; Masten \& Coatsworth, 1998; Masten et al, 2005; Masten \& Tellegen, 2012; Sameroff \& Rosenblum, 2006; Werner \& Smith, 1982, 1992, 2001) show that most young people who encounter adverse life circumstances-including chronic poverty, family disruption, and parent mental health problems-respond with resiliency, or coping and adaptation that contributes to social, academic, and vocational competence over the life span. These same studies reveal that protective factors, including support from adults outside of their families, such as teachers, contribute substantially to young people's resilience. Teacher support-often conceptualized as students' perception of teacher caring, fairness, interest, willingness to help, encouragement, listening, and efforts to be close to students-has been found to help buffer students' academic achievement from the negative effects of neighborhood and school violence (Woolley \& Bowen, 2007), depression (Reddy, Rhodes \& Mulhall, 2003), limited parent support (Gregory \& Weinstein, 2004), and family poverty (Crosnoe et al., 2010; Erickson et al., 2009; Muller, 2001; Olsson, 2009).

Teacher support appears most potent when paired with academic press, defined as an emphasis on students meeting academic standards and on achieving academic 
excellence (McDill, Natriello, \& Pallas, 1986). Lee and Smith (1999) found that that teachers' social support of students was only associated with academic achievement if students also experienced academic press, and that press without support was associated with low academic growth, if not slight regression in performance. Other scholars, particularly those concerned with the achievement of students of color and students from low-income families, also contend that support only confers substantial benefits to students when paired with high academic expectations (e.g., Antrop-González \& De Jesús, 2006; Payne, 2008; Shouse, 1996; Ware, 2006). For example, Ream (2003) calls teachers' academic lenience with Mexican-American students, which some students described as supportive, counterfeit social capital. This alleged form of support not only failed to benefit the Mexican-American students in Ream's study, but also placed them at an academic disadvantage compared to other students. Stressing the importance of teacher support intertwining with academic press, Gregory, Cornell, and Fan (2011) advocate an authoritative approach in which schools and educators blend "two seemingly opposed dimensions, variously labeled as connection versus regulation, responsiveness versus demandingness, care versus control, or support versus structure” (p. 907). In summary, this literature suggests that without academic press teacher support has weaker, if not negative, effects on student achievement.

In recent decades, teacher support has gained attention via policies that promote student-teacher relationships. Policies that advance small schools, small learning communities (SLCs), and advisory programs ${ }^{2}$ have appeared in districts across the nation in the last twenty years (Cuban, 2010; Hemphill \& Nauer, 2009; Kahne et al., 2008; Vasudeva et al., 2009), often in the name of boosting achievement among struggling students and schools. Small schools and SLCs both promote student-teacher relationships by assigning students to a smaller, bounded number of teachers, based on the assumption that when teachers have more intensive exposure to a limited number of students, they will be more able to adapt instruction, monitor student progress, exert academic press, and intervene when obstacles to academic progress or student well-being arise (Benitez, Davidson \& Flaxman, 2009; Darling-Hammond, 1997; Levine, 2010; Meier, 1995; Nieto, 2000), thereby promoting achievement.

Advisory and school-based mentoring programs similarly build in teacher support by formally requiring and reinforcing relationships between students and teachers assigned to mentor and support them (Johnson, 2009; McClure, Yonezawa \& Jones, 2010; Rhodes, 2008). Because of the spread of such policies and practices, teacher support has become a built-in part of an increasing number of teachers' jobs.

\section{Individual Teachers' Impact on Student Outcomes: Teacher Effects Research}

Despite evidence and policies that encourage teacher support as a lever for raising student academic achievement, particularly among potentially underperforming students, relatively little is known about the teacher characteristics (e.g., background, beliefs, and practices) that may contribute to the enactment of teacher support. Further, available research on student-teacher relationships typically assesses students' perceptions of their teachers as a group (e.g., Crosnoe, Johnson, \& Elder, 2004) or teachers' ratings of their own support practices (e.g., Hughes \& Kwok, 2007), rather than student responses to individual teachers. Teacher effects research, which analyzes relationships between individual teachers' characteristics and measurable student outcomes, thus offers a useful perspective that helps to frame this study.

2 While advisory programs have become prominent in secondary schools over the last few decades, they have their origin in private schools much earlier in the $20^{\text {th }}$ century, as Semel and Sadovnik (2008) noted. 
Literature in the teacher effects tradition considers how individual teachers impact student achievement and learning gains. Nye, Konstantopoulos, and Hedges (2004) found individual teacher effects on student learning outcomes, and also reported that these effects outweighed schools' effects on the same outcomes. Other scholars report evidence that particular teacher characteristics have positive, statistically significant effects on student learning. These characteristics include instructional approach (Baumert et al., 2010; Desimone \& Long, 2010; Palardy \& Rumberger, 2008; Rowan, Correnti, \& Miller, 2002), teacher certification (including national board certification) (Clotfelter, Ladd, \& Vigdor, 2007; Goldhaber \& Anthony, 2007), teacher experience (Clotfelter et al., 2007; Rowan et al., 2002), formal effectiveness ratings (Borman \& Kimball, 2005; Konstantopoulos, 2011), and teacher attitudes such as expectations and perceptions of one's own efficacy (Palardy \& Rumberger, 2008). Further, Konstantopoulos and Sun (2012) found that teachers' measured effects on student learning predicted students' learning outcomes in later school years as well.

Recent research also establishes evidence of individual teacher effects on other important student outcome domains like students' social and behavioral skills (Jennings \& DiPrete, 2010) and kindergarten readiness (Burchinal et al., 2008), as well as a variety of later-in-life outcomes such as college enrollment and quality, childbearing age, and income (Chetty, Friedman, \& Rockoff, 2011). These findings, in summary, lay the groundwork for investigating whether direct relationships exist between individual teachers' characteristics and students' perceptions of teacher support and academic press.

\section{Teacher Roles in the U.S.: Usually Constrained to Instruction}

Given our interest in teachers' engagement in supportive relationships with their students, and in teacher characteristics related to their ultimate practice, it is also critical to consider how US teachers define their roles. Teacher roles have tended to focus on the curricular instruction of students within classrooms (Jackson, 1990; Little, 1990; Lortie, 2002; Sarason, 1996). Activities beyond the classroom, like school leadership, peer mentoring, and the supervision of common areas (i.e., hall monitoring), then, are often viewed as beyond teachers' responsibilities (Bartlett, 2004; Behre, Astor, \& Meyer, 2001; Johnson \& Landman, 2000; Kilburg \& Hancock, 2006; Murphy, 2005). This same body of research suggests that teachers who extend themselves beyond classroom instruction find themselves unsupported and, at times, overwhelmed (see also Phillippo, 2010; Shiller, 2009).

Not surprisingly, given the often-narrow scope of teacher roles in the U.S., expectations for teachers to support their students in times of academic or personal distress have not always been fully specified. Grossman and associates (2007) found that teacher education lags behind other helping professions' preparation programs (e.g., clergy and psychologists) with regard to relational practices, or skills for building and maintaining professional relationships with students, although promising work is emerging in this area (McDonald Bowman \& Brayko, 2013). Teachers' familiarity with student mental health issues and child development principles have likewise been found insufficient (Koller \& Bertel, 2006; National Council for Accreditation of Teacher Education [NCATE], 2010).

Although most teachers do not receive significant training that prepares them for building and maintaining supportive relationships with students, many teachers do this work anyway (e.g., García, Arias, Murri \& Serna, 2010; Hoffman, 1996; LadsonBillings, 1994; Phillippo, 2010; Valenzuela, 1999) and often with great skill, but in a manner that Ingersoll (2003) describes as "pro-bono": at the teacher's discretion 
and unsupported. Professional learning opportunities that prepare teachers for effective student-teacher relationships remain in their early stages (e.g., Hamre et al., 2012), and do not yet occupy an established position within teacher certification programs. Considering what research literature suggests about how teachers roles have been traditionally defined and supported, one can easily see how changes to teacher roles like the advisor role, in which teachers take on responsibility for mentoring and supporting an assigned group of students, represent an expansion of the teacher role as it is commonly understood.

\section{Conceptual Framework}

Research on student-teacher relationships, teacher effects on student outcomes, and teacher role parameters creates a conceptual and empirical foundation from which to consider how teachers' role definition and role breadth might relate to teachers' support practices and, in turn, students' perceptions of teacher support. Role theory, which emphasizes the central importance of role definition to workers' actual practices, helps to tie these ideas together and to further ground this study. Figure 1, which illustrates the study's conceptual framework, shows the mechanisms that link role definition to student responses to role-driven practice.

Figure 1: Conceptual Framework Illustration. Theorized Process from Role Assignment to Student Perception

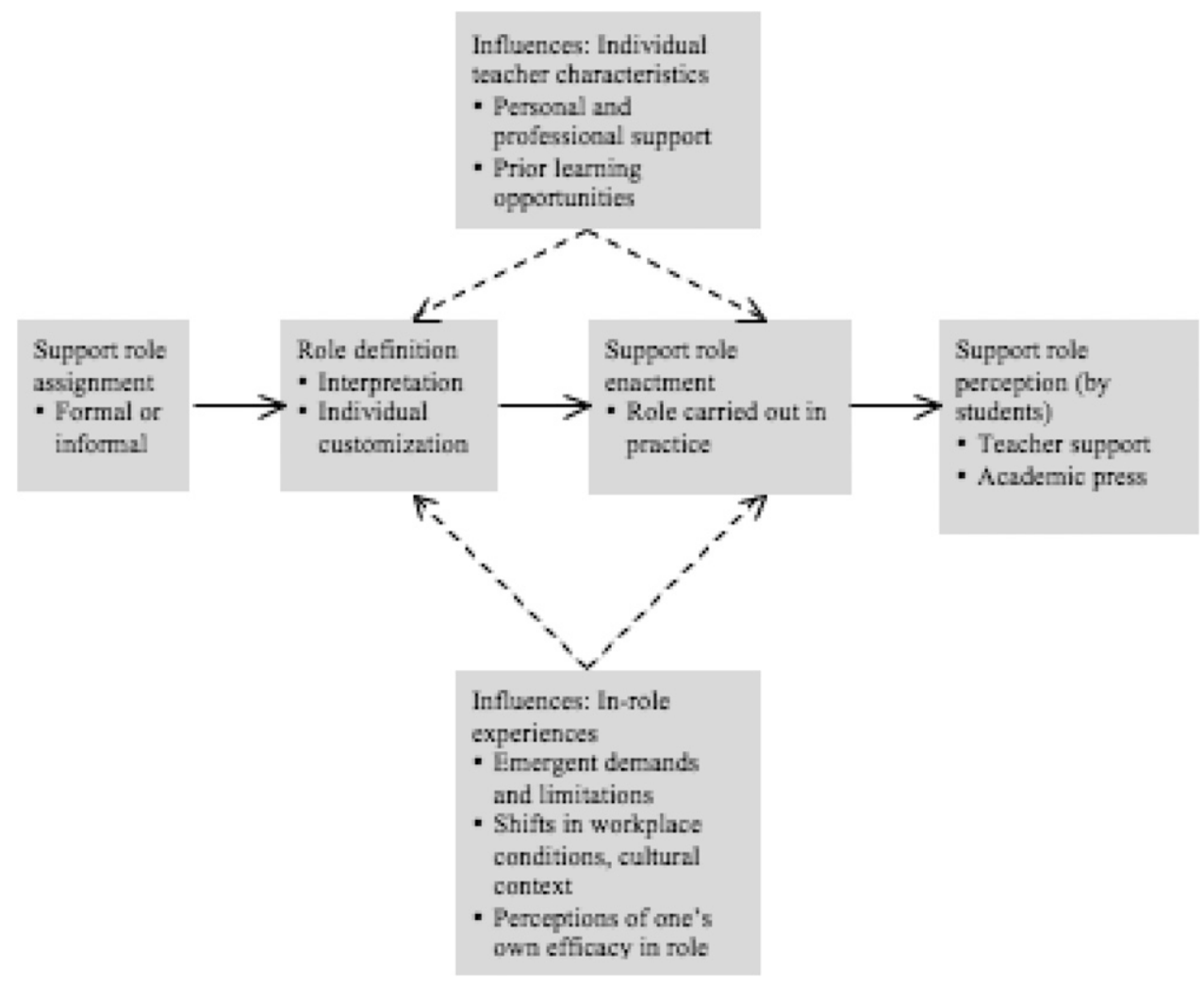

The framework starts with the assignment of the support role, which can occur informally or formally, as in the case of school requirements for teachers to assume a support role such as student advisor. The framework does not move immediately, however, from role designation to teacher practice. The mere assignment of a role 
does not necessarily convert into its performance as intended, particularly when this role represents a somewhat new demand. Earlier role theory (e.g., Bates \& Harvey, 1975; Linton, 1936; Parsons, 1951) conceptualized the professional role as normative, prescriptive, and highly stable across people and time, assuming that assigned or chosen roles govern behavior. However, subsequent theory posits that individuals negotiate and define their roles, customizing and even changing them amidst cultural, workplace and individual factors (Ashforth, Kreiner, \& Fugate, 2000; Biddle, 1997; Burke \& Stets, 2009; Turner, 1990). Therefore, we note (as illustrated in figure 1) that roles are subject to shaping by teacher definition, as well as different types of influences, as teachers enact them and as students ultimately perceive them.

Teacher efficacy beliefs are one example of a salient individual factor posited to shape how teachers carry out their role and role-related tasks. Tschannen-Moran, Woolfolk-Hoy, and Hoy (1998) defined these as teachers' beliefs about their capabilities to successfully "organize and execute courses of action" (p. 233) related to particular teaching tasks. Key sources of teacher efficacy beliefs include prior mastery experiences, vicarious experience, and persuasion (Klassen, Tze, Betts, \& Gordon, 2011). Of particular relevance to the current study, role definition and related professional responsibilities are thought to be shaped by teacher efficacy beliefs, suggesting that teachers' beliefs about their capabilities to execute such tasks shape how they define and ultimately carry out role related tasks and activities (Gibbs \& Powell, 2012).

Individuals and their characteristics do not merely influence roles; they also create and recreate roles. Baker and Faulkner (1991) contended that individuals use roles as a platform, or resource, with which they create unique positions for themselves that maximize their leverage and advantage in unique environments. Immediate demands and limitations upon the defined role (Abbott, 1988; Turner, 1990) further influence individuals' role enactment through everyday practice. Applying this perspective to teachers' work, teachers' individual characteristics (e.g., efficacy beliefs, prior preparation, skills, support networks), workplace conditions, and cultural contexts all contribute to how they define their roles, which impact role enactment and, in turn, student experience. In this conceptualization, then, teachers' role definition itself becomes another teacher characteristic capable of exerting influence on role performance (Burke \& Reitzes, 1981) and student outcomes.

Of direct relevance to this study, Somech and Oplatka (2009) illustrated the salience of role definition as a predictor variable in their study of teachers' responses to school violence. They found that the breadth of teachers' role definition-specifically, the degree to which they saw themselves as responsible for addressing violence in the school and in the classroom (e.g., intervening in violent events, incorporating violence prevention into teaching practice and curriculum)—was associated with variation in levels of student violence at their schools. In Somech and Oplatka's study, a broader, more inclusive teacher role definition, which they call role breadth, among teachers accompanied lower levels of school violence. While school conditions, specifically the support for participative management and teacher autonomy, supported role breadth related to school violence, Somech and Oplatka also identified within-school, teacher-level variation in reported role definition. This variation suggests that even under identical working conditions, teachers enact their roles with a degree of individual interpretation. This framework, in which role definition and role breadth affect teacher practice and student experience, led us to 
investigate the influence of individual teachers' chosen role breadth (related to the social-emotional support of students) upon student perceptions of teacher support and academic press.

\section{Research Questions}

Our literature review and conceptual framework led us to pose two exploratory research questions. First, to what extent does teachers' role breadth, as signified by the extent to which teachers include student support within their role as they define it, vary by teacher characteristics (e.g., individual background and experiential characteristics, efficacy beliefs, and perceptions of supports for teaching)? Second, does the degree of teachers' role breadth relate to student perceptions of teacher support and academic press (controlling for student background and school performance characteristics)?

\section{Methods}

\section{Study Design and Context}

Since our research questions were focused on teacher role definition and student responses to their teachers' role definition, we needed to collect nested student and teacher data at schools that a) explicitly required teachers to engage in supportive student-teacher relationships, and b) assigned primary responsibility for those relationships to one teacher for each student (enabling us to measure individual teachers' effects on student outcomes). A unique, observational data set, drawn from a larger comparative case study of schools' student support practices (Phillippo, 2010, 2012, 2013), enabled us to pursue our research questions. This data set consists of teacher and student surveys obtained from three small high schools in a metropolitan area of California during the 2007-2008 school year.

Two characteristics of these data are particularly notable. First, as discussed above, these schools ascribed to design features that not only promoted, but also required student-teacher relationships. All three participating schools, consistent with the small schools movement that spread across the nation during the 1990s and early 2000s (Kafka, 2008), identified as small high schools and emphasized their small enrollment as a means by which teachers could know their students well and adapt instruction to their needs. As part of emphasis on school and teacher personalism, all three schools had an advisory program where every classroom teacher served as an advisor to a group of students assigned to them for two to four years. Advisory classes met two to three times per week. School administrative staff assigned entering students (first-year or transfer) to advisory classes in a non-systematic way, minimizing the possibility that either teachers or students could select particular advisory classes. These naturally occurring assignment procedures compensated for limitations inherent in the use of observational data to make inferences about teacher-related effects, namely that students might not be assigned randomly to teachers (Nye et al., 2004), or in this case, teachers serving as advisors. Second, this data set involves separate surveys for teachers (focusing on their advisor role) and students, ultimately creating nested teacher and student data sets. This feature enabled us to consider both teacher characteristics and the extent to which those characteristics related to student outcomes of interest.

This study's database has a few characteristics that relate to the larger study's research questions and focus. Each had a majority of students of color, a range of students eligible for free or reduced-price lunch, and a range of student characteristics indicating academic and personal difficulties (such as behavioral problems in school and living apart from biological parents), characteristics that pertained to the larger 
study's research questions and focus. Table 1 provides data about the participating schools (identified by pseudonym).

\section{Table 1: School characteristics}

\begin{tabular}{|l|l|l|l|}
\hline & King & Los Robles & Western \\
\hline Total student enrollment & 358 & 295 & 345 \\
\hline Free- or reduced-price lunch & $69 \%$ & $82 \%$ & $40 \%$ \\
\hline Students of color & $97 \%$ & $99 \%$ & $91 \%$ \\
\hline Advisors of color & $23 \%$ & $33 \%$ & $44 \%$ \\
\hline $\begin{array}{l}\text { California Academic Performance Index } \\
\text { (out of 1000, statewide target of 800) }\end{array}$ & 529 & 613 & 637 \\
\hline Years open & 7 & 7 & 3 \\
\hline
\end{tabular}

No schools followed a strict advisory curriculum. King High School structured activities for advisory classes around the academic support and college readiness, while Western and Los Robles focused more on work completion (study hall style) and individualized academic and social support. Western's $11^{\text {th }}$ and $12^{\text {th }}$ grade advisory class also incorporated advisor supervision of school-required internships. All three schools provided minimal systematic training for teachers as advisors. Teachers reported learning about the advisor role in staff meetings, informal conversations with peers, and brief conversations with school administrators. Some teachers at Los Robles and King were paired with more experienced co-advisors, and some teachers at Western attended professional development related to advisory, but these experiences were the exception rather than the norm.

\section{Survey Instruments and Variables}

With the teacher survey, we strived to identify salient background characteristics, including factors that might support or discourage different types of role definition, as well as indicators of role definition. This survey had a 93\% response rate. The student survey, completed by 531 students (a $53 \%$ response rate ${ }^{3}$ ), collected information on demographic and academic characteristics, school-related difficulties and student perceptions of teacher caring and academic press. Student survey items were adapted from a well-validated instrument, the School Success Profile (Bowen \& Richman, 2008), which assesses student experiences in school via student self-report.

Teacher variables. Reflecting prior research, teacher variables included in the study fell into three overarching categories: (1) role breadth, (2) efficacy perceptions and supports related to carrying out student support tasks, and (3) teacher background, preparation, and experience. The key teacher variable in the study, role breadth, is a dichotomous indicator reflecting whether a teacher's role definition included student support. Original items that contributed to the measurement of this variable were adapted from Roeser and Midgley's (1997) study of teachers' views of student mental health issues. These items gauged the extent to which teachers agreed (using a 6-point Likert scale) that various factors comprised their definition of their role as an advisor. For example, items gauged teachers' agreement with statements including "I believe I must be both a teacher and a counselor to my students" and "The academic and social support of students are separate, distinct activities" (reverse-scored).

Using these items, we conducted exploratory factor analyses, which illuminated three underlying dimensions of their support role definition. Summed composite

3 In addition to the surveys discussed above, we excluded 64 surveys turned in by students. 30 had insufficient demographic information, and 34 others did not respond fully to teacher caring or academic press items. 
measures reflecting these dimensions included a social-emotional support definition (nine items, e.g., "I see advisory as a place where students should get whatever kind of support they need to make it through school"), a life skills support definition (four items, e.g., "I see advisory as a place where students should develop life skills"), and an academic definition (2 items, e.g., "I see advisory as a place where students should focus on academics"). Drawing upon the logic of the prior work on role breadth (Somech \& Oplatka, 2009), we defined a teacher as having a high degree of role breadth if she fell into the top quartile of two or more of the three dimensions as identified by our factor analysis. Survey items are provided in Appendix 1.

Based on our conceptual framework, the next category of teacher variables included two composites related to factors that might encourage role breadth, particularly role breadth related to teachers' support of students. The first, social support for teaching, was based on three items that asked teachers to rate (low, moderate, or high) the current degree of support for their teaching (e.g., "How would you describe your experience of administrator support at your current school?" and "How would you describe your experience of support outside of school (family, mentors, colleagues) for your teaching work?”). The Cronbach's alpha for this composite was .80. The second is a measure of teachers' sense of efficacy at tasks related to developing relationships with and supporting students (adapted from Bandura, 2006). Since, as we discussed above, teachers role definitions appear to be shaped in part by efficacy beliefs, these items gauge teachers' sense of confidence in their ability to carry out the role and its responsibilities. This 16-item composite consists of items asking teachers to rate their confidence (using a 6-point Likert scale) about performing different tasks required as part of the advisor role (e.g., "build relationships with individual students" and "collaborate with other teachers in order to support students”). The Cronbach's alpha for this measure was .92.

Finally, consistent with the teacher effects tradition that we discussed in this article's literature review, we included information on teacher background and experience characteristics. These characteristics were indicated by a series of dichotomous variables reflecting whether or not the teacher was female or male, white or nonwhite, or possessed a bachelor degree (versus a master's degree or higher). Continuous variables represented the number of years taught, and a summed 2-item composite reflecting the number of learning opportunities teachers have had related to student social-emotional support needs (e.g., "How many classes or professional development experiences have you had that focused on how to provide social or emotional support to young people?"). The Cronbach's alpha for this item was .72. Summary statistics for these items follow in Table 2.

Table 2: Teacher Characteristics $(n=45)$

\begin{tabular}{|l|c|c|c|c|}
\hline & Percent or Mean & SD & Min. & Max. \\
\hline Role breadth & $45 \%$ & & & \\
\hline Socio-emotional support efficacy & 55.5 & 11 & 20 & 72 \\
\hline Social support for teaching & 7.13 & 2.13 & 4 & 18 \\
\hline Male & $38 \%$ & & & \\
\hline Non-white & $44 \%$ & & & \\
\hline Highest degree is bachelor's degree & $22 \%$ & & & \\
\hline Years teaching & 6.43 & 6.05 & 1 & 31 \\
\hline $\begin{array}{l}\text { Learning opportunities re. student } \\
\text { social-emotional support needs }\end{array}$ & 2.78 & 2.22 & 0 & 6 \\
\hline
\end{tabular}


Student variables. Student variables fell into two categories, including (1) reports of teacher support and academic press, and (2) student background and school performance characteristics. Teacher support was measured with a 9-item composite that asked students to rate their experiences in this domain (e.g., "My teachers care whether or not I come to school" and "My teachers give me a lot of encouragement”). The Cronbach's alpha for this composite was .78. A 6-item composite asked students to rate, on a 4-point scale, their experiences of academic press (e.g., "My teachers assign work that challenges me" and "My teachers encourage me when they think I can do better”). The Cronbach's alpha for this composite was .82.

Background and performance characteristics helped us to control for student demographics and to understand how students with different life experiences perceived teacher support. In addition to student grade-level in school, other student background characteristics were indicated through a series of dummy variables reflecting (1) whether the student is male or female, (2) receiving or not receiving free or reduced lunch, (3) living with or not living with a biological parent, and (4) racial/ ethnic background (Latino excluded category). Student school performance was indicated by student report of their prior marking-period grades and a composite variable indicating the frequency of problems with in-school behavior (getting sent out of class due to misbehavior, frequency of physical fights with other students) over the previous month. Summary statistics for these items follow in Table 3.

Table 3: Student Characteristics $(n=531)$

\begin{tabular}{|l|c|c|c|c|}
\hline & $\%$ or mean & SD & Min. & Max \\
\hline Academic press & 18.64 & 3.69 & 6 & 26 \\
\hline Teacher support & 16.74 & 1.94 & 9 & 18 \\
\hline Male & $43 \%$ & & & \\
\hline Not living with biological parents & $10 \%$ & & & \\
\hline Latino & $64 \%$ & & & \\
\hline White & $12 \%$ & & & \\
\hline African-American & $13 \%$ & & & \\
\hline Asian Pacific Islander & $11 \%$ & & & \\
\hline Not receiving free or reduced lunch & $34 \%$ & & & \\
\hline Grade in school & & & & \\
\hline (\% 9th graders) & $30 \%$ & & & \\
\hline (\% 10th graders) & $28 \%$ & & & \\
\hline (\% 11th graders) & $24 \%$ & & & \\
\hline (\% 12th graders) & $18 \%$ & & & \\
\hline Grades in last marking period & 3.76 & 1.22 & 0 & 4 \\
\hline Behavior Problem Frequency & .89 & 1.39 & 0 & 8 \\
\hline
\end{tabular}

\section{Data Analysis}

Given that our data set had various levels of nesting (teachers in schools, and students within teachers' classrooms within schools), this study's analyses relied upon multi-level modeling techniques. All analyses were conducted in two steps. First, preliminary analyses assessed the extent to which there was sufficient variation to model across student, teacher and school levels (i.e., given that the sample included three compositionally similar schools, we suspected that there would be little schoollevel variation). Our preliminary analytic step was to determine the most appropriate multi-level model (e.g., students within teachers, students within teachers within schools). To address our first research question, we modeled teachers' support-inclusive 
role definition as a function of its conceptual antecedents, including social support at work and efficacy, as well as other individual characteristics (e.g., years of experience, demographic background, gender). To address our second research question, we modeled student reports of teacher support and press as a function of teachers' individual demographic background and performance characteristics as well as by teacher-reported role breadth.

\section{Results}

We report our results in the order of our research questions, first focusing on variation among teachers with regard to role breadth (related to their relationships with students and their provision of support), and then considering whether this variation predicted student perceptions of teacher support or academic press. Our first research question explored the extent to which individual teacher characteristics related to teachers' role breadth. Our analyses found that, although descriptive data suggests differences in rates of support-related role breadth across the three school sites, these did not differ notably across schools. Rather, role breadth was related to teachers' sense of efficacy at providing student support [OR $=1.17(1.05,1.31)$, $\mathrm{p}<.005$; pseudo r-squared $=.29$ ], but not to teachers' background or experience characteristics or to the support they themselves received for teaching. In other words, the most salient factor to predict teachers' role breadth was teachers' confidence about providing student support.

Our second research question explored the relationship between teachers' supportspecific role breadth, and student-reported teacher support and academic press, controlling for student background and school performance characteristics. Our preliminary analyses found that a two-level model best represented the data (students nested in teachers' advisory classrooms). Results follow below in Table 4.

Consistent with prior research (e.g., Erickson et al., 2009; Ream, 2003; Stanton-Salazar \& Dornbusch, 1995), student-reported teacher support and academic press are related to student background and performance characteristics, although social advantage did not always predict higher levels of support and press. Students who did not live with at least one biological parent also reported lower levels of press and support, while those with higher self-reported grades also reported higher levels of teacher press and support. Students who did not report receiving free lunch, representing about a third of the sample, reported lower levels of teacher support. White students, who represented about 10 percent of the sample, tended to report lower levels of academic press. Of direct relevance to our second research question, we found that students assigned to teachers with a high degree of measured role breadth reported higher levels of teacher support and also tended to report higher levels of academic press, controlling for their demographic, background and performance characteristics.

\section{Discussion and Implications}

This study utilized a unique, nested data set gathered from students and teachers in three high schools that explicitly integrated teacher support into teachers' job descriptions. Empirical literature and theory provided a foundation from which we explored the relationship between teachers' role breadth (specific to the social-emotional support of students) and student reported experiences of teacher support and academic press. In particular, we blended role theory and research on student-teacher relationships and teacher effects to frame our investigation of how individual teachers' role definition related to student outcomes of interest. We found that teachers' role breadth was related to their efficacy about providing student support, but not 
Table 4: Multi-level model of student reported teacher support and academic press

\begin{tabular}{|c|c|c|}
\hline & $\begin{array}{l}\text { Teacher Support } \\
\text { B (SE) }\end{array}$ & $\begin{array}{l}\text { Academic Press } \\
\text { B (SE) }\end{array}$ \\
\hline \multicolumn{3}{|l|}{ Student-level covariates } \\
\hline Intercept & $\begin{array}{l}15.83 * * * \\
(.33)\end{array}$ & $\begin{array}{l}16.10^{* * *} \\
(1.90)\end{array}$ \\
\hline Male & $\begin{array}{l}.03 \\
(.17)\end{array}$ & $\begin{array}{l}.17 \\
(.32)\end{array}$ \\
\hline Not living with biological parents & $\begin{array}{l}-.69^{*} \\
(.28)\end{array}$ & $\begin{array}{l}-1.13^{*} \\
(.53)\end{array}$ \\
\hline White & $\begin{array}{l}-.37 \\
(.29)\end{array}$ & $\begin{array}{l}-1.00^{+} \\
(.54)\end{array}$ \\
\hline African American & $\begin{array}{l}-.16 \\
(.25)\end{array}$ & $\begin{array}{l}.49 \\
(.47)\end{array}$ \\
\hline Asian Pacific Islander & $\begin{array}{l}-.28 \\
(.27)\end{array}$ & $\begin{array}{l}-.24 \\
(.51)\end{array}$ \\
\hline Not receiving free or reduced-price lunch & $\begin{array}{l}-.63^{*} \\
(.30)\end{array}$ & $\begin{array}{l}-.73 \\
(.57) \\
\end{array}$ \\
\hline Tenth grader & $\begin{array}{l}.12 \\
(.25)\end{array}$ & $\begin{array}{l}.73 \\
(.45)\end{array}$ \\
\hline Eleventh grader & $\begin{array}{l}.24 \\
(.29)\end{array}$ & $\begin{array}{l}.21 \\
(.53)\end{array}$ \\
\hline Twelfth grader & $\begin{array}{l}.44 \\
(.33)\end{array}$ & $\begin{array}{l}.97 \\
(.59)\end{array}$ \\
\hline Grades & $\begin{array}{l}.18^{* *} \\
(.07)\end{array}$ & $\begin{array}{l}.47^{* * *} \\
(.13)\end{array}$ \\
\hline Behavior problems & $\begin{array}{l}-.14 \\
(.10)\end{array}$ & $\begin{array}{l}.13 \\
(.19)\end{array}$ \\
\hline Level 1 Variance component & 12.52 & 3.34 \\
\hline \multicolumn{3}{|l|}{ Teacher-level covariates } \\
\hline Role breadth & $\begin{array}{l}.62^{*} \\
(.25)\end{array}$ & $\begin{array}{l}.72^{+} \\
(.44)\end{array}$ \\
\hline Level 2 Variance component & .41 & .26 \\
\hline
\end{tabular}

Note: ${ }^{+}=\mathrm{p}<.10,{ }^{*}=\mathrm{p}<.05,{ }^{* *}=\mathrm{p}<.01,{ }^{* * *}=\mathrm{p}<.001$.

to their background and experience characteristics or social supports for teaching. Further, we found that teachers' role breadth was associated with student-reported teacher support and academic press, controlling for key background and school performance characteristics.

Our findings suggest that teacher role breadth may represent a salient teacher effect related to student perceptions of teacher support and academic press. Our findings also suggest that efforts to increase teacher efficacy in the domain of providing student support may bolster role breadth that would, in turn, contribute to student perceptions of teacher support and subsequent increases in student achievement. Below, we discuss each of these findings as well as their implications.

First, this study's student-level outcomes strongly suggest that teacher role definition matters with regard to student perceptions of both teacher support and academic press. Our findings pinpoint an association between teacher role breadth and the kinds of student experiences (teacher support and academic press) that prior research 
links to student academic achievement. As such, our findings complement and extend other research literature that supports a broad notion, beyond that of strictly academic instruction, of how teachers impact their students' learning experiences. Indeed, our findings problematize the distinction between nonacademic and academic studentteacher interactions, if one understands students' experiences of teacher support and academic press as coming across to students during day-to-day student-teacher interactions. Teacher support, as our survey items measured it, came across as a mixture of academic and social-emotional support. Teachers, then, stand in a position to boost student achievement by providing a range of supports across different kinds of interactions with their students.

As such, our student-level findings have implications for how teachers frame their roles and in turn carry out their work each day. If teachers take on broader roles that include student support and strong student-teacher relationships, the evidence reported above gives us reason to expect that their students will notice and respond positively to this role breadth. Given previous research that establishes the impact of teacher support and academic press on student academic outcomes, teacher role breadth (and the teaching practice it implies) presents another potential opportunity to promote student achievement.

This implication is particularly relevant to less socially- and educationally-advantaged student populations. Erickson et al. (2009) found that these groups have a lower likelihood of encountering teacher support but a higher likelihood of benefiting from it as indicated by increased rates of high school graduation and college enrollment. This subgroup of students' regular encounters with teachers who embrace a broader role appeared to render them more likely to reap the academic benefits of strong student-teacher relationships. However, given our knowledge that teachers sometimes perceive a need for, and provide, support based on student characteristics (rather than on students' stated support needs) (Barber, 2002; Ream, 2003; RolónDow, 2005; Stanton-Salazar, 1997), we are concerned to see statistically-significant differences in levels of student-perceived student support across demographic, life experience, and academic dimensions. Teacher efforts to boost students' academic and personal well-being via student-teacher relationships and social support must be socio-culturally attuned so as not to pathologize or patronize students who possess genuine strengths and supports in their lives, just as teachers should not falsely neglect students who might not meet their mental image of a student in need of teacher support. Recent research on culturally relevant student-teacher relationships (Antrop-González \& De Jesús, 2006; Garza, 2009; Lewis et al., 2012; Phillippo, 2012) stands to guide teachers' work in this area.

What else is necessary to better scaffold broadly defined teacher roles? Here, we fold in one of the study's other major findings: that teachers' sense of efficacy in providing support emerged as a predictor of teacher role breadth. If education administrators, policymakers or researchers are considering whether to promote student academic achievement by encouraging teachers to take on support responsibilities like the advisor role, this finding suggests they need to promote teachers' efficacy in this domain. Research indicates that teacher efficacy is malleable through individual and situational factors (e.g., Klassen, Tze, Betts, \& Gordon, 2011) and thus suggests the importance of mastery experiences, vicarious experience, and persuasion. Given that our survey items focused on teachers' efficacy at providing student support (e.g., recognizing signs of student substance abuse, responding to students in crisis, connecting students with needed support resources, collaborating with colleagues and parents), it seems that efforts to bolster teacher practice related 
to student support would enhance teachers' efficacy in this domain. Such interventions or supports might include additional learning opportunities through coursework or professional development experiences, explicit expectations about student support provided by schools, and guidance, particularly coaching, from administrators or school-based mental health practitioners (Tschannen-Moran \& McMaster, 2009). Efforts to help teachers learn how to build student-teacher relationships (e.g., Hamre et al., 2012) promises to boost teacher efficacy regarding these potentially powerful support practices.

Efforts to build teachers' efficacy about their work supporting students, however, would not be highly consistent with the current state of teacher education or school organization. Teachers in our sample mirror the field at large, in that both groups received little training or support in student-support related competencies (Grossman et al., 2007; Koller \& Bertel, 2006; NCATE, 2010). We suspect that a lack of relevant learning opportunities, which Table 2 indicates fall below an average of 3 courses or professional development sessions, partly explains our finding that teachers' learning experiences had no statistically significant relationship to teachers' role definition. Future research is needed to better understand the nature of pre-service training in these areas, as well as how they are later addressed through professional development, as well as what strategies or experiences support teacher role definitions, behaviors, and, ultimately, interactions with students.

Similarly, the school organization itself might scaffold and reinforce teachers' support practices. Such organizational practices may challenge the traditional role definitions, which tend to differentiate teaching students from supporting them, with school-based professionals other than teachers (e.g., school psychologists, counselors, and social workers) often occupying the "turf" of student support (Lortie, 2002; Phillippo \& Stone, 2011). Additional school-based assistance related to teachers' support role might take the form of in-house training, consultation, or role specification, but would also run counter to prevailing norms in how schools organize and deliver student support, and the kinds of narrow role-related expectations that teachers tend to encounter.

Research in this area might also run into resistance, or limited support, as it spans beyond traditional parameters of educational research. Efforts to broaden teachers' roles into the realm of social-emotional support would require substantial effort to implement effectively. However, our results suggest that such efforts may pay off with regard to students' subsequent experiences of teacher support that could in turn contribute to increased student achievement. If, by contrast, teachers are left on their own to define their roles related to student support, both their practice and their efficacy will vary according to individual skill and inclination. Such variation would result in continued unequal distribution of support opportunities for students.

Additionally, we found it interesting that teachers' experience of support for their own work with students did not show a relationship with teachers' role breadth, given that role theorists conceptualize workplace conditions and resources as important antecedents for role definition. We suspect that this finding may relate to an inherent limitation of our study-the limited amount and range of schools sampled. This limitation may also have suppressed school-level influences on teachers' role definition or students' experiences of teacher support and academic press. Research that replicates or extends our line of inquiry with a broader, more diverse sample of schools would address these limitations.

Additionally, the intentional assignment of advisor roles to teachers in our participating schools was an important sampling and methodological asset, in that it enabled 
us to look at a range of teachers enacting the advisor role and not just teachers who voluntarily shaped their roles in this direction. However, it may also have constrained variation in teachers' role-related decision making. More observational studies, which attempt to understand how teachers initially enact support-related roles, are also warranted. Finally, research on teachers' support practices could expand further with the development and use of measures and data collection strategies beyond survey data that may better capture actual teacher practices, the hypothesized mechanism that links role definition and student experiences of teacher support and academic press.

We also note the limitations of using student self-report data. While students are considered a key reporter of perceptions of the school environment and our measures derived from the well-validated School Success Profile, which considered the advantages and drawbacks to student self-report data and incorporated those considerations while field testing the SSP (see Bowen, Rose \& Bowen, 2005 for discussions of the field testing process used), it is important to note that student reports of press and personalism are mediated through a wider school context. Future research should include measures of student perceptions of these phenomena at both the advisory and the school level.

Despite these noteworthy limitations, our findings suggest that blending concepts from student-teacher relationship literature, teacher effects research, and role theory is a potentially fruitful avenue for investigating and understanding teacher influences on academically related student outcome domains, beyond instructional effects. This study's findings highlight the importance of teachers' influence on students' experiences of teacher support and academic press. As such, we hope to remind education policymakers, teacher educators, researchers, administrators and, above, all, teachers, of the many routes of influence that teachers have over student experiences that ultimately contribute to achievement.

\section{References}

Abbott, A. (1988). The system of professions: An essay on the division of expert labor. Chicago: University of Chicago Press.

Anfara, V. A. (2006). Research summary: Advisory programs. Westerville, OH: National Middle School Association. Retrieved June 25, 2010, from http://www.nmsa.org/Research/ResearchSummaries/ AdvisoryPrograms/tabid/812/Default.aspx

Antrop-González, R., \& De Jesús, A. (2006). Toward a theory of critical care in urban small school reform: examining structures and pedagogies of caring in to Latino community-based schools. International Journal of Qualitative Studies in Education, 19(4), 409-433.

Ashforth, B. E., Kreiner, G. E., \& Fugate, M. (2000). All in a day's work: Boundaries and micro role transitions. Academy of Management Review, 25(3), 472-491.

Baker, W. E., \& Faulkner, R. R. (1991). Role as resource in the Hollywood film industry. American Journal of Sociology, 97(2), 279-309.

Bandura, A. (2006). Guide for creating self-efficacy scales. In F. Pajares \& T. Urdan (Eds.), Self-efficacy beliefs of adolescents (pp. 307-337). Greenwich, CT: Information Age.

Barber, T. (2002). "A special duty of care" Exploring the narration and experience of teacher caring. British Journal of Sociology of Education, 23(3), 383-395.

Bartlett, L. (2004). Expanding teacher roles: A resource for retention or a recipe for overwork? Journal of Education Policy, 19(5), 565-582.

Bates, F. L., \& Harvey, C. C. (1975). The structure of social systems. New York, NY: Wiley and Sons.

Baumert, J., Kunter, M., Blum, W., Brunner, M., Voss, T., Jordan, A.,..\& Tsai, Y. M. (2010). Teachers, Mathematical Knowledge, Cognitive Activation in the Classroom, and Student Progress. American Educational Research Journal, 47(1), 133-180.

Behre, W. J., Astor, R. A. \& Meyer, H. (2001). Elementary- and middle-school teachers' reasoning about intervening in school violence: An examination of violence-prone school subcontexts. Journal of Moral Education, 30(2), 131-153.

Benitez, M., Davidson, J., \& Flaxman, L. (2009). Small schools, big ideas: The essential guide to small school transformation. New York, NY: Wiley.

Biddle, B. J. (1997). Recent research on the role of the teacher International Handbook of Teachers and Teaching (Part 1). Norwell, MA: Kluwer. 
Borman, G. D., \& Kimball, S. M. (2005). Teacher quality and educational equality: Do teachers with higher standards-based evaluation ratings close student achievement gaps? Elementary School Journal, 106(1), 3-20.

Bourdieu, P. (1986). The forms of capital. In J. Richardson (Ed.), Handbook of theory and research for the sociology of education (pp. 241-258). New York, NY: Greenwood.

Bowen, G. L., \& Richman, J. M. (2008). The School Success Profile (5th ed.). Chapel Hill, NC: Jordan Institute for Families, School of Social Work, the University of North Caroina at Chapel Hill.

Bowen, G. L., Rose, R. A., \& Bowen, N. K. (2005). The reliability and validity of the School Success Profile. Philadelphia, PA: Xlibris Press.

Brewster, A. B., \& Bowen, G. L. (2004). Teacher support and the school engagement of Latino middle and high school students at risk of school failure. Child and Adolscent Social Work Journal, 21(1), 47-67.

Bryk, A. S., Sebring, P. B., Allensworth, E., Luppescu, S., \& Easton, J. Q. (2010). Organizing schools for improvement: Lessons from Chicago. Chicago, IL: University of Chicago Press.

Burchinal, M., Howes, C., Pianta, R. C., Bryant, D., Early, D., Clifford, R., \& Barbarin, O. (2008). Predicting child outcomes at the end of kindergarten from the quality of pre-kindergarten teacher-child interactions and instruction. Applied Developmental Science, 12(3), 140-153.

Burke, P. J., \& Reitzes, D. C. (1981). The link between identity and role performance. Social Psychology Quarterly, 44(2), 83-92.

Burke, P. J., \& Stets, J. E. (2009). Identity Theory. New York, NY: Oxford.

Burns, J., Jenkins, J. B., \& Kane, J. T. (2011). Advisory: Finding the Best Fit for Your School. Westerville, $\mathrm{OH}$ : Association for Middle Level Education.

Coleman, James S. (1988). Social capital in the creation of human capital. American Journal of Sociology, 94, Supplement, S95-S120.

Chetty, R., Friedman, J. N., \& Rockoff, J. E. (2011). The long-term impacts of teachers: Teacher valueadded and student outcomes in adulthood. Cambridge, MA: National Bureau of Economic Research.

Clotfelter, C. T., Ladd, H. F., \& Vigdor, J. L. (2007). Teacher credentials and student achievement: Longitudinal analysis with student fixed effects. Economics of Education Review, 26(6), 673-682.

Croninger, R. G., \& Lee, V. E. (2001). Social capital and dropping out of high school: Benefits to at-risk students of teachers' support and guidance. Teachers College Record, 103(4), 548-581.

Crosnoe, R., Johnson, M. K., \& Elder, G. H., Jr. (2004). Intergenerational Bonding in School: The Behavioral and Contextual Correlates of Student-Teacher Relationships. Sociology of Education, 77(1), 60.

Crosnoe, R., Morrison, F., Burchinal, M., Pianta, R. C., Keating, D., Friedman, S. L., \& Clarke-Stewart, K. A. (2010). Instruction, teacher-student relations, and math achievement trajectories in elementary school. Journal of Educational Psychology, 102(2), 407-417.

Cuban, L. (2010). As good as it gets: What school reform brought to Austin. Cambridge, MA: Harvard University Press.

Darling-Hammond, L. (1997). The right to learn: A blueprint for creating schools that work. San Francisco: Jossey-Bass.

Darling-Hammond, L., Haertel, E., Amrein-Beardsley, A., \& Rothstein, J. (2012). Evaluating teacher evaluation. Phi Delta Kappan, 93(6), 8-15.

Desimone, L. M., \& Long, D. (2010). Teacher effects and the achievement gap: Do teacher and teaching quality influence the achievement gap between black and white and high- and low-SES students in the early grades? Teachers College Record, 112(12), 3024-3073.

Erickson, L. D., McDonald, S., \& Elder, G. H. (2009). Informal mentors and education: Complementary or compensatory resources? Sociology of Education, 82(4), 344-367.

Galassi, J. P., Gulledge, S. A., \& Cox, N. D. (1997). Middle school advisories: Retrospect and prospect. Review of Educational Research, 67(3), 310-338.

García, E., Arias, M. B., Murri, N. H., \& Serna, C. (2010). Developing responsive teachers: A challenge for demographic diversity. Journal of Teacher Education, 61(1-2), 132-142.

Garland, S. (2012). Using value-added data to evaluate Tennessee teachers. The Hechinger Report. Retrieved from http://hechingerreport.org/content/7581_7581/

Garza, R. (2009). Latino and white high school students' perceptions of caring behaviors. Urban Education, 44(3), 297-321.

Gibbs, S. \& Powell, B. (2012), Teacher efficacy and pupil behaviour: The structure of teachers' individual and collective beliefs and their relationship with numbers of pupils excluded from school. British Journal of Educational Psychology, 82, 564-584.

Goldhaber, D., \& Anthony, E. (2007). Can teacher quality be effectively assessed? National board certification as a signal of effective teaching. The Review of Economics and Statistics, 89(1), 134-150.

Gregory, A., Cornell, D., \& Fan, X. (2011). The Relationship of School Structure and Support to Suspension Rates for Black and White High School Students. American Educational Research Journal, 48(4), 904-934.

Gregory, A., \& Weinstein, R. S. (2004). Connection and regulation at home and in school: Predicting growth in achievement for adolescents. Journal of Adolescent Research, 19(4), 405-427.

Grossman, P., Compton, C., Shahan, E., Ronfeldt, M., Igra, D., \& Shaing, J. (2007). Preparing practitioners to respond to resistance: a cross professional view. Teachers and teaching: Theory and Practice, 13(2), 109-123.

Hallett, R. E. (2011). Educational experiences of hidden homeless teenagers: Living doubled up. New York, NY: Routledge. 
Hamre, B. K., Pianta, R. C., Burchinal, M., Field, S., LoCasale-Crouch, J., Downer, J. T., . . . Scott-Little, C. (2012). A Course on Effective Teacher-Child Interactions. American Educational Research Journal, 49(1), 88-123.

Hamre, B. K., \& Pianta, R. C. (2005). Can instructional and emotional support in the first-grade classroom make a difference for children at risk of school failure? Child Development, 76(5), 949-967.

Hanushek, E. A. (2011). The economic value of higher teacher quality. Economics of Education Review, 30(3), 466-479.

Hemphill, C., \& Nauer, K. (2009). The new marketplace: How small-school reforms and school choice have reshaped New York City's high schools. New York: Center for New York City Affairs.

Hetherington, E. M., \& Kelly, J. (2002). For better or for worse: Divorce reconsidered. New York, NY: Norton.

Hill, C., \& Kearl, H. (2011). Crossing the line: Sexual harassment at school. Washington, D.C.: American Association of University Women.

Hoffman, M. (1996). Chasing hellhounds: A teacher learns from his students. Minneapolis: Milkweed Editions.

Hughes, J. N., \& Kwok, O. (2007). Influence of student-teacher and parent-teacher relationships on lower achieving readers' engagement and achievement in the primary grades. Journal of Educational Psychology, 99(1), 39-51.

Hughes, J. N., Luo, W., Kwok, O. M., \& Loyd, L. K. (2008). Teacher-student support, effortful engagement and achievement: A three-year longitudinal study. Journal of Educational Psychology, 100(1), $1-14$.

Ingersoll, R. (2003). Who controls teachers' work? Power and accountability in America's schools. Cambridge, MA: Harvard University Press.

Jackson, P. W. (1990). Life in classrooms (2nd ed.). New York: Teachers College Press.

Jennings, J. L., \& DiPrete, T. A. (2010). Teacher effects on social and behavioral skills in early elementary school. Sociology of Education, 83(2), 135-159.

Johnson, B. (2009). Linchpins or lost time: Creating effective advisories. Horace, 25, 2-3.

Johnson, C., Eva, A. L., Johnson, L., \& Walker, B. (2011). Don’t Turn Away: Empowering Teachers to Support Students' Mental Health. The Clearing House: A Journal of Educational Strategies, Issues and Ideas, 84(1), 9-14.

Johnson, S. M., \& Landman, J. (2000). “Sometimes bureaucracy has its charms”: The working conditions of teachers in deregulated schools. Teachers College Record, 102(1), 85-124.

Kafka, J. (2008). Thinking big about getting small: An ideological geneaology of small-school reform. Teachers College Record, 110(9), 1802-1836.

Kahne, J. E., Sporte, S. E., de La Torre, M., \& Easton, J. Q. (2008). Small high schools on a larger scale: The impact of school conversions in Chicago. Educational Evaluation and Policy Analysis, 30(3), 281-315.

Kilburg, G. M., \& Hancock, T. (2006). Addressing sources of collateral damage in four mentoring programs. Teachers College Record, 108(7), 1321-1338.

Klassen, R. M., Tze, V. M. C., Betts, S. M., Gordon, K. A. (2011). Teacher efficacy research 1998-2009: Signs of progress or unfulfilled promise? Education Psychology Review, 23, 21-43.

Klem, A., \& Connell, J. P. (2004). Relationships matter: Linking teacher support to student engagement and achievement. Journal of School Health, 74(7), 262-273.

Koller, J. R., \& Bertel, J. M. (2006). Responding to today's mental health needs of children, families and schools: Revisiting the preserve training and preparation of school-based personnel. Education and Treatment of Children, 29(2), 197-217.

Konstantopoulos, S. (2011). Teacher effects in early grades: Evidence from a randomized study. Teachers College Record, 113(7), 1541-1565.

Konstantopoulos, S., \& Sun, M. (2012). Is the persistence of teacher effects in early grades larger for lowerperforming students? American Journal of Education, 118, 309-339.

Kumashiro, K. (2012). Bad teacher! How blaming teachers distorts the bigger picture. New York: Teachers College Press.

Ladson-Billings. (1994). The dreamkeepers: Successful teachers of African American Children. San Francisco: Jossey Bass.

Langenkamp, A. G. (2010). Academic Vulnerability and Resilience during the Transition to High School: The Role of Social Relationships and District Context. Sociology of Education, 83(1), 1-19.

Lee, V. E., \& Smith, J. B. (1999). Social support and achievement for young adolescents in Chicago: The role of school academic press. American Educational Research Journal, 36(4), 907-945.

Levine, T. H. (2010). What research tells us about the impact and challenges of smaller learning communities. Peabody Journal of Education, 85(3), 276-289.

Lewis, J., Ream, R. K., Bocian, K. M., Cardullo, R. A., Hammand, K. A., \& Fast, L. A. (2012). Con Cariño: Teacher Caring, Math Self-Efficacy, and Math Achievement Among Hispanic English Learners. Teachers College Record, 114(7), 1-42.

Lieber, C. M., \& Poliner, R. A. (2004). The advisory guide: Designing and implememting effective advisory programs in secondary schools. Cambridge, MA: Educators for Social Responsibility.

Lin, N. (2001). Social capital: A theory of social structure and action. New York, NY: Cambridge University Press.

Linton, R. (1936). The study of man. New York, NY: Appleton-Century.

Little, J. W. (1990). The persistence of privacy: Autonomy and initiative in teachers' professional relations. Teachers College Record, 91(4), 509-536.

Lortie, D. C. (2002). Schoolteacher: A sociological study (2nd ed.). Chicago: University of Chicago Press. 
Martin-Storey, A., \& Crosnoe, R. (2012). Sexual minority status, peer harassment and adolescent depression. Journal of Adolecence, 35(4), 1001-1011.

Masten, A. S., \& Coatsworth, J. D. (1998). The development of competence in favorable and unfavorable environments: Lessons from successful children. American Psychologist, 53, 205-220.

Masten, A. S., Roisman, G. I., Long, J. D., Burt, K. B., Obradovic, J., Riley, J. R., . . . \& Tellegan, A. (2005). Developmental Cascades: Linking Academic Achievement and Externalizing and Internalizing Symptoms Over 20 Years. Developmental Psychology, 41(5), 733-746.

Masten, A. S., \& Tellegen, A. (2012). Resilience in developmental psychopathology: Contributions of the Project Competence Longitudinal Study. Development and psychopathology, 24(2), 345-361.

McClure, L., Yonezawa, S., \& Jones, M. (2010). Can school structures improve teacher student relationships? The relationship between advisory programs, personalization and students' academic achievement. Education Policy Analysis Archives, 18(17), 1-21.

McDill, E. L., Natriello, G., \& Pallas, A. M. (1986). A population at risk: Potential consequences of tougher school standards for student dropouts. American Journal of Education, 94(2), 135-181.

McDonald, M. A., Bowman, M., \& Brayko, K. (2013). Learning to see students: Opportunities to develop relational practices through community-based placements in teacher education. Teachers College Record, 115(4).

Meier, D. (1995). The power of their ideas: Lessons for America from a small school in Harlem. Boston: Beacon Press.

Mihalas, S., Morse, W. C., Allsopp, D. H., \& McHatton, P. A. (2009). Cultivating Caring Relationships Between Teachers and Secondary Students With Emotional and Behavioral Disorders Implications for Research and Practice. Remedial and Special Education, 30(2), 108-125.

Miller, P. M. (2011). A Critical Analysis of the Research on Student Homelessness. Review of Educational Research, 81(3), 308-337.

Muller, C. (2001). The role of caring in the teacher-student relationshiop for at-risk students. Sociology of Inquiry, 71(2), 241-255.

Murphy, J. (2005). Connecting Teacher Leadership and School Improvement. Thousand Oaks, CA: Corwin Press.

National Council on the Accreditation of Teacher Education. (2010). The road less traveled: How the developmental sciences can prepare educators to improve student achievement. Washington, D.C.: Author.

Nieto, S. (2000). A gesture toward justice: Small schools and the promise of equal education. In W. Ayers, M. Klonsky \& G. H. Lyon (Eds.), A simple justice: The challenge of small schools. (pp. 13-17). New York: Teachers College Press.

Nye, B., Konstantopoulos, S., \& Hedges, L. V. (2004). How large are teacher effects? Educational Evaluation and Policy Analysis, 26(3), 237-257.

Olsson, E. (2009). The role of relations: Do disadvantaged adolescents benefit more from high-quality social relations? Acta Sociologica, 52(3), 263-286.

Palardy, G. J. \& Rumberger, R. W. (2008). Teacher effectiveness in first grade: The importance of background qualifications, attitudes, and instructional practices for student learning. Educational Evaluation and Policy Analysis, 30, 111-140.

Parsons, T. (1951). The Social System. Glencoe, IL: Free Press.

Payne, C. M. (2008). So much reform, so little change: The persistence of failure in urban schools. Cambridge, MA: Harvard Education Press.

Phillippo, K. L. (2010). Teachers providing social and emotional support: A study of complex role enactment in small high schools. Teachers College Record, 112(8), 2258-2293.

Phillippo, K. L. (2012). "You're trying to know me": Students from nondominant groups respond to teacher personalism. Urban Review, 44(4), 441-467.

Phillippo, K. L. (2013). Advisory in urban high schools: A study of expanded teacher roles. New York, NY: Palgrave Macmillan.

Phillippo, K. L., \& Stone, S. I. (2011). Towards a broader view: A call to integrate knowledge about schools into school social work research. Children \& Schools, 33(2), 71-81.

Ream, R. K. (2003). Counterfeit social capital and Mexican-American underachievement. Educational Evaluation and Policy Analysis, 25(3), 237-262.

Reddy, R., Rhodes, J. E., \& Murhall, P. (2003). The influence of teacher support on student adjustment in the middle school years: A latent growth curve study. Development and psychopathology, 1, 119-138.

Rhodes, J. E. (2008). Improving youth mentoring interventions through research-based practice. American Journal of Community Psychology, 41(1), 35-42.

Robinson, J. P., \& Espelage, D. L. (2011). Inequities in educational and psychological outcomes between LGBTQ and straight students in middle and high school. Educational Researcher, 40(7), 315-330.

Robinson, J. P., \& Espelage, D. L. (2012). Bullying Explains Only Part of LGBTQ-Heterosexual Risk Disparities: Implications for Policy and Practice. Educational Researcher, 41(8), 309-319.

Roeser, R. W., \& Midgley, C. (1997). Teachers' views of issues involving students' mental health. The Elementary School Journal, 98(2), 115-133.

Rolón-Dow, R. (2005). Critical care: A color(full) analysis of care narratives in the schooling experiences of Puerto Rican girls. American Educational Research Journal, 42(1), 77-111.

Roorda, D. L., Koomen, H. M. Y., Spilt, J. L., \& Oort, F. J. (2011). The Influence of Affective TeacherStudent Relationships on Students' School Engagement and Achievement. Review of Educational Research, 81(4), 493-529.

Rosenfeld, L. B., Richman, J. M., Bowen, G. L., \& Wynns, S. L. (2006). In the face of a dangerous community: The effects of social support and neighborhood danger on high school students' school outcomes. Southern Communication Journal, 71(3), 273-289. 
Rothstein, R. (2012). Teacher accountability and the Chicago teachers strike. http://www.epi.org/blog/ teacher-accountability-chicago-teachers/

Rowan, B., Corrienti, R., \& Miller, R. (2002). What Large-Scale Survey Research Tells Us About Teacher Effects on Student Achievement: Insights from the Prospects Study of Elementary Schools. Teachers College Record, 104(8), 1525-1567.

Sameroff, A. J., \& Rosenblum, K. L. (2006). Psychosocial constraints on the development of resilience. Annals of the New York Academy of Sciences, 1094(1), 116-124.

Sarason, S. B. (1996). Revisiting “The culture of the school and the problem of change”. New York: Teachers College Press.

Semel, Susan F., \& Sadovnik, A. R. (2008). The contemporary small-school movement: Lessons from the history of progressive education. Teachers College Record, 110(9), 1744-1771.

Shiller, J. T. (2009). “These are our children!” An examination of relationship-building practices in urban high schools. The Urban Review, 41(5), 1573-1960.

Shouse, R. C. (1996). Academic press and school sense of community: Conflict, congruence, and implications for student achievement. Social Psychology of Education, 1(1), 47-68.

Shulkind, S. B., \& Foote, J. (2009). Creating a culture of connectedness through middle school advisory programs. Middle School Journal, 41(1), 20-27.

Somech, A., \& Oplatka, I. (2009). Coping with school violence through the lens of teachers' role breadth: The impact of participative management and job autonomy. Educational Administration Quarterly, 45(3), 424-449.

Stanton-Salazar, R. D. (1997). A social capital framework for understanding the socialization of racial minority children and youths. Harvard Educational Review, 67(1), 1-40.

Stanton-Salazar, R. D. (2010). A Social Capital Framework for the Study of Institutional Agents and Their Role in the Empowerment of Low-Status Students and Youth. Youth \& Society, 43(3), 1066-1109.

Stanton-Salazar, R. D., \& Dornbusch, S. M. (1995). Social capital and the social reproduction of inequality: The formation of information networks among Mexican-origin high school students. Sociology of Education, 68(2), 116-135.

Tschannen-Moran, M., Hoy, A. W., \& Hoy, W. K. (1998). Teacher efficacy: Its meaning and measure. Review of Educational Research, 68(2), 202-248.

Tschannen-Moran, M., \& McMaster, P. (2009). Sources of self-efficacy: Four professional eevelopment formats and their relationship to self-efficacy and implementation of a new teaching strategy. The Elementary School Journal, 110(2), 228-245.

Turner, R. H. (1990). Role change. Annual Review of Sociology, 16, 87-110.

Valenzuela, A. (1999). Subtractive schooling: U.S. Mexican youth and the politics of caring. Albany, NY: State Univeristy of New York Press.

Vasudeva, A., Darling-Hammond, L., Newton, S., \& Montgomery, K. (2009). Oakland Unified School District new small schools initiative evaluation. Stanford, CA: School Redesign Network at Stanford University.

Ware, F. (2006). Warm demander pedagogy: Culturally responsive teaching that supports a culture of achievement for African American students. Urban Education, 41(4), 427-456.

Werner, E. E., \& Smith, R. S. (1982). Vulnerable but invincible: A longitudinal study of resilient children and youth. New York: McGraw-Hill.

Werner, E. E., \& Smith, R. S. (1992). Overcoming the odds: High risk children from birth to adulthood. Ithaca, NY: Cornell University Press.

Werner, E. E., \& Smith, R. S. (2001). Journeys from childhood to midlife: Risk, resilience and recovery. Ithaca, NY: Cornell University Press.

Woolley, M. E., \& Bowen, G. L. (2007). In the context of risk: Supportive adults and the school engagement of middle school students. Family Relations, 56(1), 92-104.

\section{8}

\section{Appendix 1: Survey items used for composite variables}

\section{Teacher survey items}

Role breadth items, statements rated by teachers on a six-point Likert scale, ranging from "strongly disagree" to "strongly agree."

1. I believe I must be both a teacher and a counselor to my students.

2. My primary role is to teach students, not to attend to their feelings and emotions

3. I think professionals other than me, such as school counselors and social workers, should take primary responsibility for my students' mental health and well being. 
4. I cannot teach my students effectively unless I also consider their social and emotional needs.

5. I play an important role not only in my students' learning, but also in the way they feel about themselves and life in general.

6. I frequently think about my students' mental health and well being.

7. I see advisory as a place where students should develop life skills.

8. The advisory role interferes with my ability to teach my other classes.

9. The academic and social support of students are separate, distinct activities.

10. I see advisory as a place where students should focus on academics.

11. The advisory role is a central part of my job.

12. I see advisory as a place where students should get whatever kind of support they need to make it through school.

13. I see advisory as a place where students should be prepared for college and/or career.

14. I have a "big picture" plan for my advisory class.

Efficacy (related to student support) items, statements rated by teachers on a five-point Likert scale, ranging from "not at all confident" to "highly confident."

1. Build relationships with individual students

2. Notice social-emotional troubles in your students

3. Start conversations with students when you are concerned about their well-being

4. Recognize signs of mental health issues (e.g., depression, trauma)

5. Recognize signs of family violence

6. Recognize signs of substance abuse

7. Recognize signs that a student is suicidal

8. Respond to your students when they misbehave in school

9. Respond to your students when they tell you about their troubles

10. Respond to your students when they are experiencing a crisis

11. Connect students with support or resources they might need

12. Share concerns about students' well-being with their parents/guardians

13. Collaborate with other teachers in order to support students

14. Collaborate with administrators in order to support students

15. Collaborate with support staff (counselor, social worker) in order to support students

16. Collaborate with parents in order to support students

Social support for teaching items, rated by teachers as low, moderate or high.

1. How would you describe your experience of peer support at your current school?

2. How would you describe your experience of administrator support at your current school?

3. How would you describe your experience of support outside of school (such as family, mentors) for your teaching work?

\section{Student items}

Teacher support items, rated by students as "true” or "false."

1. My teachers care about me.

2. My teachers listen to what I have to say.

3. My teachers care whether or not I come to school. 
4. My teachers are willing to work with me after school.

5. My teachers give me a lot of encouragement.

6. My teachers praise my efforts when I work hard.

7. My teachers care about the grades I make.

8. My teachers show me respect.

9. My teachers know my strengths as a student.

Teacher academic press items, rated by students on a four-point Likert scale, ranging from "strongly disagree" to "strongly agree."

1. My teachers expect me to do my best.

2. My teachers challenge me to do better in school.

3. My teachers let me know when I am doing my best work.

4. My teachers assign work that challenges me.

5. My teachers tell me when I am doing less than my best work.

6. My teachers encourage me when they think I can do better.

Behavior problem items, reported by students as "never," "one or two times” or "three or more times."

During the past 30 days, how often did any of the following things happen?

1. I was sent out of class because I misbehaved.

2. My parent/guardian received a warning about my attendance, grades or behavior.

3. I got in a physical fight with another student.

4. I was given an out-of-school suspension. 